Original Research Paper

\title{
Processes of Acculturation Khakases (Indigenous People of Southern Siberia), Living Outside of the Khakassia in the Urban and Student Environment
}

\author{
${ }^{1}$ Natalia Koptseva and ${ }^{1,2}$ Vladimir Kirko \\ ${ }^{1}$ Department of Cultural Studies, Siberian Federal University, Krasnoyarsk, Russia \\ ${ }^{2}$ Department of Management Organizations, Krasnoyarsk State Pedagogical University Named after Victor Astafijev, \\ Krasnoyarsk, Russia
}

\author{
Article history \\ Received: 2014-05-04 \\ Revised: 2014-09-10 \\ Accepted: 2015-01-02 \\ Corresponding Author: \\ Natalia Koptseva, \\ 1Department of Cultural \\ Studies, Siberian Federal \\ University, Krasnoyarsk, \\ Russia \\ E-mail: decanka@mail.ru
}

\begin{abstract}
This article represents an applied research to form principles of state and regional policy preserve the unique culture of Khakassia-the indigenous people of Southern Siberia (Russia). Presents the results of sociological research strategy of acculturation Khakases who live in the urban and students living environment of the city of Krasnoyarsk (Siberia, Russia). The basic approach of this study is a combination of the scientific problems of theoretical ideas J. Berri about the kinds of strategies of acculturation and sociological survey among the students who have Khakassia origin, to find out which strategy is dominated by acculturation: Assimilation, separation, integration and marginalization. Important variables that we measured and controlled are the content of ethnic identity of students who were born and raised in Khakassia, they are ethnic Khakasses, but they are university students in the Krasnoyarsk Territory, where live and study Russian and the main language is Russian. Underlining that the main strategy of acculturation young Khakases in the Krasnoyarsk-is the strategy of assimilation. The conclusions of the study are based on the discussion of the results of sociological and cultural studies Khakasian ethnic and cultural groups in 2014.
\end{abstract}

Keywords: Applied Social Research, The Indigenous People, Southern Siberia, Ethnic Groups, Khakases, Acculturation, Assimilation

\section{Iintroduction}

Berry (2005) secured in a cross-cultural research, the concept of 'acculturation' (Berry et al., 2002), a lot of research, where this concept has proved extremely popular. Acculturation processes are closely related to migration, they are of great importance for a modern economy (Rezaei, 2007; Ubonlert et al., 2009). The study of acculturation strategies necessary for understanding the basic rituals of social life in traditional (non-industrial) societies, for the study of social movements in different countries (Phukhronghin et al., 2010; Thongwol et al., 2010; Simvised et al., 2008). The social life of the indigenous peoples of the world is the most important issue of many modern scientific fields (Ward, 2011; Zare et al., 2008; Chaiyatorn et al., 2010). Of particular importance are the processes of acculturation in societies where living together three or more ethnic and cultural groups.

Post-Soviet Russia is precisely this type of society. In every region of Russia live together a multitude of ethnic groups. Interethnic relations are of great importance for modern Russia. A large number of ethnic groups are living in Siberia. Interethnic relations in modern Siberia represent Cathedral choice of acculturation strategies in different ethnic groups. One of the largest multi-ethnic regions of Siberia is the Krasnoyarsk region.

Relevance of the proposed research is that due to the historical conditions of the Krasnoyarsk Territory has always been kind of the epicenter of interethnic interactions. Acculturation processes in modern Siberia do not always have a positive outcome. Interethnic relations have sometimes a conflictual development. Research makes the prevention of interethnic conflicts. Interethnic relations in modern Siberia reflect the total situation in post-Soviet Russia.

In the Krasnoyarsk region according to All-Russian census 2010 inhabited by 136 ethnic groups. Ethnic groups, inhabiting the territory of Krasnoyarsk region, for several centuries created its industrial, intellectual and cultural potential. Factor of interethnic accord is an important prerequisite for the development of the 
Krasnoyarsk Territory, maintaining social, political and economic stability.

Historically formed ethno-cultural space of the Krasnoyarsk Territory has specific features, which cause many ethnic and cultural groups living on its territory, including indigenous peoples. Khakases (ethnonym: Skhakastar, tadar, hooray) are an indigenous people the Southern Siberia Russian Federation. The principal place of compact residence of Khakases is the Republic of Khakassia in which Khakases has about 65,400. In addition, they inhabit the neighboring regions, which are home to about 4,500, including the Republic of Tuva and Krasnoyarsk live Khakases 1, 2 thousand.

The Republic of Khakassia cooperates with the Krasnoyarsk region as an autonomous territorial entity. It is known that in the Krasnoyarsk region is home to about 4500 Khakases that is a consequence of employment or educational migration. In the city of Krasnoyarsk are formed youth ethnic and cultural group of Khakassia, which has its public organization 'NAA TAN'. This organization has been around for several years and has been organizing social and cultural activities to unite Khakasian youth, cohesion and cultural development, conservation Khakasian traditions outside the Republic of Khakassia. During the work, the organization has conducted numerous socio-cultural activities for young people, the most important of which are traditional holidays Chyl Grooves (celebration of the New Year according to the lunar calendar), Tun-Pyro (holiday Khakasian pastoralists, which is held in late May), as well as activities such as 'Miss Asia-Siberia', etc. In early June of this year, the organization plans to hold an event for youth Khakasian 'Interzemlyachestvo'. Since 1990, the Krasnoyarsk's Khakassia Public Association was converted in 1996 in Khakassia National Cultural Center, which was a part formed in the same year as Interethnic Cultural Center.

Despite the fact that young workers and students who came to Krasnoyarsk from Khakassia, created ethnic and cultural community organizations, municipal and student environment change their attitude towards their own ethnic and cultural group. Acculturation strategies, which are selected young Khakases Krasnoyarsk are changed. Modern urban and student environment affects the choice of acculturation strategies of young Khakases. The process of ethnogenesis Khakases has specificity for Khakasian youngsters who became students in Krasnoyarsk.

The purpose of this study has to figure out the specifics of this. Many researchers believe that modern Khakassia have a tendency to separatism. However, they do not take into account the processes of urbanization and processes that change in the ethnic identity in the student and urban environment.

\section{Materials and Methods}

Modern cultural studies uses interdisciplinary methods .This study was conducted at the intersection of sociology, ethnology, political science. Dominant sociological research methods were methods that seek to identify the principles of behavior of social groups (in this case, ethnic and cultural groups) and methods of regulating this behavior. The possibilities of using sociological methods for cultural studies have been demonstrated in a number of specific works. In modern cultural studies scholars actively apply the following sociological methods: Sociological observations with subsequent interpretation of empirical (Giddens, 1991; Radugin and Radugin, 1999). The sociological survey method is the most popular method and is widely used in cross-cultural studies (Osgood, 1988; Korotaev, 1994).

In the Siberian Federal University since 2010 constantly researching processes of ethnic identification of indigenous peoples of the North and Siberia (Koptseva, 2013; Kirko et al., 2012; Koptseva and Kirko, 2014a; 2014b; Reznikova, 2013; Semenova, 2010; Nevolko, 2012; Krivonogov, 2013a; Makarov, 2013; Luzan, 2011; Batashev, 2013; Prathumnet, 2011; Prathumnet et al., 2010). The basic method is fieldwork and subsequent analysis of the results of field studies During the field research methods are applied social and cultural sciences. Study of the processes of ethnic identity of indigenous peoples is very important to assist indigenous peoples to adapt to modern society. The State Policy of Russia has regulations (including Federal Laws) that require public authorities to assist in the preservation of the unique culture of indigenous peoples of the North and Siberia. Research helps clarify the specifics of processes of ethnic identification of indigenous peoples, indicate 'weak points' in the State and Regional Policy.

In this study the survey method was used as a kind of a sociological survey. This method is relevant not only because it greatly reduces the time of the study, but also allows mobile work with the same data. The structure of sociological questionnaire consists of demographic questionnaire, brief instructions for use of the questionnaire and of the questionnaire (Table 1). Survey process includes a number of provisions:

- Greeting and a short message to the respondent future research objectives

- Direct questioning of respondents with associated commentary questions (on demand)

- Processing of the results of the questionnaire

- Interpretation of the data

Profile of a poll on the topic: 'Inter-ethnic relations in the territory of the united Krasnoyarsk Territory'

Dear participant! It is sociological questionnaire. Its purpose-research. We ask you to participate in this research study and help us to jointly address pressing problems of intercultural relations (participation anonymous).

The study was conducted in March 2014 in the city of Krasnoyarsk. Respondents were members of the youth 
Khakasian ethnic and cultural groups residing in the city. Subject of research-of young Khakases acculturation processes (cross-cultural and inter-ethnic relations) in the city of Krasnoyarsk. Purpose of the study was to obtain information about the sociological processes of acculturation as characteristic Khakasian ethnic and cultural groups in the Krasnoyarsk Territory.

\section{Results}

We can conclude that the basic strategy of acculturation, which selects the modern youth Khakases ethnic and cultural group-it is a strategy of assimilation. Below are findings which support this conclusion.

Currently in Krasnoyarsk are moderate migration processes Khakasian ethnic representatives that are characteristic of the youth subculture than for middleaged people. The sample survey has got 68 women and 42 men. Most of them have a 'student age' from 18 to 25 years (79 people). About 21 people work in the city of Krasnoyarsk, their ages ranging from 26 to 30 years.

On the first question about the conduct of inter-ethnic policy in the Krasnoyarsk region the majority of respondents replied that this policy is not carried out (35\%), many find it difficult to answer $(20 \%)$, some have noted that there are attempts $(10 \%)$, not many have heard about the fact that this policy really is $(15 \%)$. Of the public authorities of the Krasnoyarsk region, which implement cultural policy in the field of interethnic relations respondents, of proposed alternatives, noted the Ministry of culture of Krasnoyarsk region (32\%), the Agency on Affairs of the North and support of indigenous peoples $(15 \%)$. Young people are also convinced that such a policy is conducted and private organizations of the Krasnoyarsk region (25\%), 20\% believe that there are attempts, $10 \%$ believe that not carried out and $35 \%$ found it difficult to answer. Such organizations respondents include trade organization (35\%), recreational facilities $(20 \%)$ and educational institutions $(15 \%)$. The answer is 'available' replied $10 \%$ of respondents.

On the issue of interaction with representatives of other nationalities, the majority of respondents said that they do not interact (50\%), interact regularly-25\% and rarely-5\%. On the question of the events that organize regional and municipal authorities, $65 \%$ noted that 'not invited' and invite quite rare-5\%. In Krasnoyarsk region by the efforts of the state and various public ethnocultural organizations are ethnic cultural celebrations. In this regard, the young people state that national holidays they like $(75 \%)$, rarely like $(12 \%)$,'t like them $(10 \%)$, $10 \%$ do not attend such events. However, most respondents indicated that they did not attend the event of other ethno-cultural groups $(75 \%)$ or are of such events are quite rare $(25 \%)$.
On the issue of the type of settlement, inhabited by the respondents, the majority of respondents mentioned cities with the population over 100 thousand people $(85 \%)$. For assistance in organizing their national activities in the state bodies $61 \%$ did not appeal, some believe that it is useless to 34 and $4 \%$ go for help in conducting national-cultural activities in the public authorities of the Krasnoyarsk territory. This is a small percentage of 'collaborating' with the power structures are the staffs of the Youth Khakasian organization 'NAA TAN', which actively carry out and organize the Khakasian ethnic holidays in the city of Krasnoyarsk.

Many young people have a positive attitude to their ethnic celebrations were attended by the delegations of other ethno-cultural groups (65\%), neutral viewpoint $(15 \%)$. But not one Respondent did not answer that applies to this presence in the negative.Representatives of youth Khakases ethnic and cultural groups point out the following national autonomy with which they have the most friendly relations: Armenian (75\%), Kyrgyz (2\%); Azerbaijan (3\%); China (1\%); Tatar (10\%); no such relations $(10 \%)$.

Russian ethno-cultural group Khakases young people do not consider 'foreign' or independent ethno-cultural group. However, among the Khakases youth there is a saying 'we among strangers, a stranger among us', who means that the difference between the Russians and the Khakasian ethnic groups, they do not see, if not to take into account the traditional ethno-cultural traditions.

The answers of young respondents to the question about the meaning of the term "tolerance" can be grouped in 4 groups: 1.-'mutual respect' (45\%), 2.-'to take into account features of other national cultures' (25\%), 3.-'love' (1\%), 4.-'no answer' (29\%).

The phrase 'ethnic cultural cooperation' respondents understand interchange $(13 \%)$, but most of them find it difficult to answer $(87 \%)$.

On the issue of social control of modern ethnic and cultural processes the majority of respondents indicated the answer "should not be regulated" $(72 \%), 26 \%$ believe that control efforts should be focused on developing a common culture, $2 \%$ believe that efforts should be directed towards the adoption of other cultural traditions.

Abour $47 \%$ of young people say that for the Krasnoyarsk region not common practice prejudice to national groups, the remaining $63 \%$ of respondents did not answer this question.

The final question of the nature of ethno-cultural relations in the Krasnoyarsk region the respondents said that the atmosphere of interethnic relations in the region, at present, positive- $73 \%$, unstable- $19 \%$, no answer- $4 \%$.

\section{Discussion}

Research of processes of acculturation Khakases, living in the Krasnoyarsk Region, revealed that the main strategy of acculturation for this people is assimilation. 
Table 1. Questionnaire for the opinion poll Khakassian students

Is there a real Russian State Policy in the

field of international relations?

What are public authorities or public institutions makes cultural policy in the field of international relations (unless noted in the first question option a) or b)?

Is there, in Your view, private organizations policy in the field of interethnic relations?

\section{Name the types of private organizations}

engaged in cultural policy in the field of interethnic relations (if the first question noted option a) or b).

Do You operate with representatives of other national autonomies?

You are invited to important events that organize regional or municipal administration?

Do You like ethnic cultural celebrations that are held in the Krasnoyarsk territory?

You visit the feasts organized by representatives of other ethnic groups?

Name the category of the settlement, which is predominantly populated by representatives of Your ethnic autonomy.

You turn for help to the bodies of state power or state organizations when carrying out their own activities?

How do You feel about the fact that ethnic holidays may be present delegations of other ethnic groups?

What ethnic autonomy with which You have the friendliest relations?

Do You think the state should be the regulator of international relations?

How do You understand the term 'tolerance'? What do You think, what is the purpose of the contemporary ethnic and cultural processes? a) Yes, of course

b) There are attempts

c) Not done

d) No answer

a) the Ministry of culture

b) The administration of Krasnoyarsk region

c) The House of culture

d) Those are absent

a) Yes, of course

b) There are attempts

c) Not done

d) No answer

a) Trade organization

b) Entertainment facilities

c) Educational institutions

d) Non

a) Yes, regularly

b) Rarely

c) Do not interact

d) No answer

a) Yes, regularly

b) Rarely

c) Not done

d) No answer

a) Like

b) Rarely like

c) Not like

d) I don't attend such events

a) Regularly

b) Rarely

c) Not done

d) Visit by invitation only

a) Rural settlements

b) Cities with population of 5 thousand to 20 thousand

c) Cities with population of 50 thousand to 100 thousand

d) Cities with the population over 100 thousand

e) Krasnoyarsk

a) Regularly

b) Rarely

c) Not done

d) It's useless

a) Positive

b) Neutral

c) Negative

d) No answer

a) Armenian

b) Kyrgyz

c) Azerbaijani

d) Chinese

e) Tatar

f) German

g)

h)

a) Should

b) Not always

c) Categorically should not

d) It should be made by ethnic group

a) Self-determination

b) Borrowing other cultural traditions

c) Formation of a unified culture

d) These processes have no purpose 
Table 1. Continue

How do you think there is in society of the

Krasnoyarsk Territory practice prejudice against

persons of any ethnic and cultural groups?

How one word can describe the inter-ethnic relations in the Krasnoyarsk territory?

Your sexual identity

Your Age

Your level of education

Your profession

Thank you for your attention and help!

This conclusion clarifies the opinion expressed Belozerova (2008), which believes that the peoples of southern Siberia constantly show a desire to separatism and choose strategy of acculturation is separation. Belozerova (2008) argues that the processes of separatism can be open or latent character. Stabilization of the socio-economic and socio-cultural processes at the end of XX-beginning of XXI century leads to the fact that the strategy of separation is replaced by a strategy of assimilation.

Krivonogov (1997) argued that in the end of XX century the Khakases was no generic-consciousness, he noted that the process of ethnic identification moved into the sphere of culture and art, and that further development of ethnogenesis will show, what the significance of Khakasian ethnic art for ethnogenesis is. The study Krivonogov (2013b) by development of Khakasian literary language argues that the development of cinema, radio, Internet at the Khakasian languages, development of Khakasian literary language has a positive effect on the ethnogenesis of Khakases. The development of Khakas ethnic identity V.P. Krivonogov is connected with development of means of mass communication at the Khakasian language, with the development of Khakas ethnic art and literature. Thus, research by V.P. Krivonogov confirms the findings of our research. V.P. Krivonogov shows that ethnic identification modern Khakases inextricably linked with the processes of development of Khakasian language. But these processes are insufficient and also confirm the findings of our study are that the strategy of assimilation prevails for Khakases.

Sokolovsky (2008) believes that although Khakases are an indigenous people of Siberia, but their economic well-being depends on the economy,
a) Yes
b) There are isolated manifestations
c) Non
d) Oblivious
a) Positive
b) Unstable
c) Explosive
d) No answer

a) Up to 20 years old

b) From 20 at 30 years old

c) From 30 at 45 years old

d) From 45 years old

a) Secondary education

b) Secondary technical education

c) Incomplete higher education

d) Higher education

a) Worker

b) Serviceman

c) Employee of the cultural field

d) Employee of the private organization

e)

which is associated with the Russian population of Siberia. Consequently, the strategy of assimilation must be reinforced over time. Our study extends the findings that made Sokolovsky (2008).

Inkizhekova (2010) concludes that the strategy of acculturation Khakases currently defined actions ethnic elites Khakases. It Khakasian elite (entrepreneurs and intellectuals) have taken a lot of effort into the processes of ethnic identity of Khakases should connect with the strategy of separation. In our study involved Khakases, which had not experienced the active influence of Khakasian elites. Therefore, we can refine the conclusion of the Inkizhekova (2010). If Khakases not have direct influence of ethnic and political elites, they choose the strategy of assimilation. Strategy separation inherent Khakasian elites, but not all, Khakases.

Kolchikova (2012) explores the features of ethnic identity at Khakases students. She concludes that belonging to Khakassia causes more negative emotions of students than belonging to a Russian. Conclusion by (Kolchikova, 2012) confirmed by our research: Students Khakases seek assimilation rather than separation.

Nevolko (2011) conducted a study of art processes, characteristic of modern Khakasian masters. She concluded that the processes of ethnic identity in modern Khakases more associated with the visual arts and creative writing. Ethnic identification Khakases has no support in modern Russian economy and politics. This study confirms the findings indirectly (Koptseva and Seredkina, 2013) that the strategy of separation is not characteristic of modern Khakassia, the processes of ethnic identity Khakases are virtual.

Tkachenko (2014) suggests that modern Khakassia chosen strategy of separation because they appreciate 
the traditional culture of their ancestors. Tkachenko (2014) in her study said that the study was conducted in rural areas in the school environment. Consequently, our study adds to research of (Tkachenko 2014), as our informants-are urban residents, students who are urbanized lifestyle.

\section{Conclusion}

The results show that the members of the youth group Khakases migrate to the city of Krasnoyarsk and prerequisites for to perform migration, first of all is receive education and work. Krasnoyarsk attracts by Khakases youth in cultural space, availability of 'entertainment centers'. The majority of representatives of youth Khakases group answered that they do not see differences in the choice of their place of residence between Krasnoyarsk or Abakan (the capital of the Republic of Khakassia). It also confirms the thesis that in the process of adaptation of Khakases ethnic group chooses the most convenient strategy of assimilation.

The result of this strategy, obviously traced in everyday culture of modern Khakases. Gradually disappears traditional culture of Khakassia ethnos. This trend is worrying young representatives of the Khakases ethnic and cultural groups, who say that their ethnic culture needs to preserve, develop and maintain. However, the mechanisms for this support they do not know.

Future research areas related to the study of changes in self-identification of students who belong to ethnic and cultural groups of the Yakuts, Evenki, Nenets-Siberian Arctic indigenous peoples who live and study in the universities of the Krasnoyarsk Territory. The results of these studies will be used to develop advanced technologies in higher education, the adaptation of indigenous peoples of the Siberian Arctic for urban life, the theory of ethnic pedagogy in higher education of Russia.

Research is limited to the study of processes of selfidentification of indigenous peoples in the first third of the 21 st century and the study of the choice of acculturation strategies for students who come from the indigenous peoples of the Siberian Arctic.

\section{Acknowledgment}

The paper was written with the support of a grant of KGAU "Regional Fund for support of science and scientific and technical activities".

\section{Author's Contributions}

All authors equally contributed in this work.

\section{Ethics}

This article is original and contains unpublished material. The corresponding author confirms that all of the other authors have read and approved the manuscript and no ethical issues involved.

\section{References}

Batashev, M.S., 2013. Ethnic history of indigenous peoples of the yeniseysky uyezd in the 17 century and their fortunes. Humanities Social Sci., 6: 842-869.

Belozerova, M.V., 2008. On the problem of separatism among the indigenous peoples of Southern Siberia: XX century. Bulletin Tomsk State Univ., 7: 69-73.

Berry, J.W., 2005. Acculturation: Living successfully in two cultures. Int. J. Intercultural Relations, 29: 697712. DOI: 10.1016/j.ijintrel.2005.07.013

Berry, J.W., Y.H. Poortinga, M.H. Segall and Dasen, P.R., 2002. Cross-Cultural Psychology. Research and Applications, Cambridge University Press.

Chaiyatorn, S., P. Kaoses and P. Thitphat, 2010. The developmental model of cultural tourism-homestay of the lao vieng and lao song ethnic groups in the central region of Thailand. J. Soc. Sci., 6: 130-132. DOI: $10.3844 /$ jssp.2010.130.132

Giddens, A., 1991. Modernity and Self-identity: Self and Society in the Late Modern Age. 1st Edn., Stanford University Press, Standford, Calif, ISBN-10: 0804719446, pp: 256.

Inkizhekova, M.S., 2010. Ethnic and Political Elites of Khakassia Republic as a Socio-Cultural Phenomenon. 1st Edn., Kazan, Homeland, pp: 107.

Kirko, V.I., L.M. Fatkulina-Yaskova and V.V. Zaharuta, 2012. The estimation of the state of objects in the settlements of evenki and taimyr autonomous districts. Humanities Social Sci., 9: 1287-1290.

Kolchikova, N.L., 2012. The ethnic identity among students Khakases. Tomsk, TSPU Herald, 4: 17-21.

Koptseva, N. and V. Kirko, 2014. Ethic identification of indigenous people of the Siberian arctic. Am. J. Applied $\quad$ Sci., 11 : 1573-1577. DOI: 10.3844/ajassp.2014.1573.1577

Koptseva, N.P. and N.N. Seredkina, 2013. Construction of positive ethnic identity in a multicultural system. Krasnoyarsk, Siberian Federal University.

Koptseva, N.P. and V.I., Kirko, 2014. Specificity of ethnogeny indigenous peoples by Central Siberia in the transition from the traditional type of society to modern society. Life Sci. J., 11: 409-413.

Koptseva, N.P., 2013. The results of theoretical and experimental research of the modern problems of the indigenous small-numbered peoples of the North, Siberia and the Far East in Siberian Federal University. Humanities Social Sci., 5: 762-772. 
Korotaev, A.V., 1994. Apologia for 'the sabaean cultural political area'. Bulletin School Oriental Afr. Stud., 57: 469-474. DOI: 10.1017/S0041977X00008879

Krivonogov, V.P., 1997. Khakassia. Ethnic Processes in the Second Half of XX Century. 1st Edn., Centaurus, Abakan, pp: 142.

Krivonogov, V.P., 2013a. The dolgans' ethnic identity and language processes. Humanities Social Sci., 6: $870-881$.

Krivonogov, V.P., 2013b. Khakass dialects and literary language. Khakassian ethnicity at the turn of XXXXI centuries. Abakan. Khakassia Book Publishers, pp. 7-11.

Luzan, V.S., 2011. Peculiarities of legal regulation of socio-cultural development of native smallnumbered peoples of the north, Siberia and the Far East under the conditions of global transformations. Humanities Social Sci., 5: 678-687.

Makarov, N.P., 2013. The ancient stages of the culture genesis of the Krasnoyarsk northern indigenous peoples. Humanities Social Sci., 6: 816-841.

Nevolko N.N., 2011. Visualization ethnic theme in paintings and graphic works of art Khakassian masters. Humanities Social Sci., 8: 1109-1126.

Nevolko, N.N., 2012. The national visual art in the process of formation and preservation of the ethnic identity of indigenous peoples (by the example of Khakass visual art). Humanities Social Sci., 8: 1179-1198.

Osgood, C.E., 1988. Psycholinguistics, Cross-Cultural Universals, and Prospects for Mankind. 1st Edn., Praeger Publishers, ISBN-10: 0030594332.

Phukhronghin, W., S. Chantachon and S. Laoakka, 2010. Phi Ti Su Khwan: Conservation and transmission of the spiritual encouragement-ritual of people in Isan society. J. Soc. Sci., 6: 386-388. DOI: 10.3844 jssp.2010.386.388

Prathumnet, N., 2011. The new frontiers of edutainment: An application of indigenous knowledge for conservation and development of the production process of silk cloths. J. Soc. Sci., 7: 412-414. DOI: $10.3844 /$ jssp.2011.412.414

Prathumnet, N., S. Chantachon, K. Paengsoi, N. Thongwol and B. Saenyabud, 2010. An application of indigenous knowledge for conservation and development of the production process of silk cloths. J. Soc. Sci., 6: 330-332. DOI: 10.3844 jssp.2010.330.332
Radugin, A.A. and K.A. Radugin, 1999. Sociology. 1st Edn., Moscow. Center, pp: 160.

Rezaei, S., 2007. Breaking out: The dynamics of immigrant owned businesses. J. Soc. Sci., 3: 94-105. DOI: $10.3844 /$ jssp.2007.94.105

Reznikova, K.V., 2013. Preservation and transformation of certain aspects of the traditional way of life of the indigenous and small-numbered peoples of the north, living in the Settlements (Posyolki) of Turukhansk and Farkovo. Humanities Social Sci., 6: 925-939.

Semenova, A.A., 2010. Modern practices of foresight research of the future of social-anthropological systems, including ethnical cultural populations. Humanities Social Sci., 5: 667-676.

Simvised, P., S. Chantachon and S. Rittidech, 2008. A study of models of life quality development of isan marginal communities as affected by installation of the solar home system. J. Soc. Sci., 4: 272-274. DOI: $10.3844 /$ jssp.2008.272.274

Sokolovsky, S.V., 2008. On the meaning of the concept of 'indigenous people': Discussion. Ethnographic Rev., 4: 60-76.

Thongwol, N., J. Tammawat, P. Rittidej and B. Saenyabud, 2010. The social movement of the phuan in Thailand. J. Soc. Sci., 6: 293-295. DOI: $10.3844 /$ jssp.2010.293.295

Tkachenko, N.V., 2014. The study of ethnic identity Khakases in mono-ethnic environment. Actual problems of socio-psychological knowledge. Theoretical Practical Prob. Psychol., 1: 75-83.

Ubonlert, W., S. Chantachon and W. Engwanich, 2009. The Adaptation of fishing instruments by a farmers' community in the Thung Kula Area, in North Eastern Thailand. J. Soc. Sci., 5: 112-116. DOI: $10.3844 /$ jssp.2009.112.116

Ward, M.K., 2011. Teaching indigenous American culture and history: Perpetuating knowledge or furthering intellectual colonization? J. Soc. Sci., 7: 104-112. DOI: 10.3844 /jssp.2011.104.112

Zare, S., H.S. Fami and M. Namiranian, 2008. People participation, an undeniable necessity for conserving forest areas of arasbaran region in Iran. Am. J. Agric. Biol. Sci., 3: 673-680. DOI: 10.3844 /ajabssp.2008.673.680 